\title{
THE PERMANENT NEUTRALITY TREATIES
}

The present European war has thrown into sharp relief the status of those smaller governments which, although in nowise shorn of attributes of sovereignty within their own borders, have nevertheless been placed by virtue of most solemn international guarantees in a position of perpetual neutrality towards all other Powers. They are not to wage offensive warfare, nor, if the obligations resulting from these guarantees are faithfully observed, may their territories be in any degree the theatre of hostilities. While the chief examples of this peculiar status,Belgium, Luxemburg and Switzerland,-are plainly, by reason of restricted area and population, in no condition to cope with the greater powers surrounding them, it is not alone their lack of size or strength that has marked them out for permanent neutrality or neutralization, but rather their essential relation to the map of Europe and the many conflicting interests innate in its geographical outlines which have seemed to make necessary their fixed withdrawal from plans of rivalry or territorial ambition and the creation in this manner of certain inter-spaces destined for peace whatever may be the fate of their more powerful neighbors.

The precise conditions of such a neutrality are to be found in a long line of treaties and agreements comprising within their horizon a great variety of objects. For the purpose of the present examination, however, we shall lay out of detailed view all aspects of permanent neutrality save those attaching to the three governments just named since to consider the various phases of the subject would require much more space than that at the disposal of a single article. The conception, nevertheless, of such a fixed immunity from oppression or obstruction either commercial or belligerent in character has assumed within the past century, and in various parts of the globe, forms of the most interesting nature and is well deserving of the most serious study on the part of all interested in international relations. As examples we may instance the case of the greater international rivers, such as the Congo and Niger, thrown-open by the Berlin convention of 1885 to navigation of every description and at all times without trammels, either commercial or political, save such slight tolls as may be imposed to meet the necessary maintenance 
of light and pilotage; ${ }^{1}$ similarly, the Danube, by virtue of the treaties of London ( $187 \mathrm{I}$ ) and of Berlin (I878), with the explanatory convention of $1883,{ }^{2}$ is in charge on its lower course from Ibraila to the Black Sea of a European Commission whose activities have resulted in a great waterway along which shipping may pass without physical obstruction and with the lightest practicable charges; so the Rhine, by the international navigation convention of I868 (Rhein-Schaffahrts-Akte), is in charge of a permanent commission whose home is at Mannheim; so with the Danube's great affluent, the Pruth, as well as with smaller but not less important streams such as the Scheldt, the Elbe, the Pô (before its banks were wholly Italian), and other lesser streams, the formerly oppressive navigation dues have been removed or lightened and these pathways of commerce made the highways that nature intended them to be. Another phase of our subject might be found in the great Danish waterways, the Sounds and Belts $;^{4}$ in the Straits of Magellan declared free by Chile and Argentina in $1881 ;$ in the Suez Canal made effectively neutral by international coöperation in I888, the process being completed in the Anglo-French agreement of $1904 ;^{6}$ in our Panama waterway, although this latter lacks the stamp of international agreement ; ${ }^{\top}$ still another aspect may be instanced in the Ionian Island group devoted to neutrality by international

\footnotetext{
1 The Congo documents are to be found in de Martens' treaties: "Nouveau Recueil Général," sér. 2, page 4I4, etc. Rivier, Lehrbuch des Volkerrechts, considers the subject comprehensively in \$I7: die internationalen Flusse; v. Liszt gives the recent literature in his Völkerrecht at p. 203 seq. (6th ed. I9ro).

${ }^{2}$ De Martens, loc. cit. 9, 392, etc.

The question of the Rhine has given rise to many conventions; of these, the principal one is that of Oct. I7, I868 (de Martens, loc. cit. Ist series, vol. 20 , p. 355).

"Tréaty of Copenhagen, March 14, 1857 (Martens, vol. 16, Ist series, p. 345 . The United States made a separate treaty by which $\$ 393,0$ II was paid to commute navigation dues in the Sound and Belts: Malloy's Treaties, etc., of the United States, vol. I, p. 380 . To the foregoing list may well be added the Weser (treaties of I820, I856); the Meuse (I8I5); the Oder, Vistula, Niemen, Rio de la Plata, etc.

${ }^{5}$ De Martens, Nouveau Recueil Général, 2me série, XII, 49I.

-De Martens, XV, 557.

TTreaty with New Grenada (Colombia), Dec. 12, 1846; with Great Britain, Nov. 18, Igor (Hay-Pauncefote treaty); with Panama, Nov. 18, I903; with Colombia, January 9, I909, and not ratified by the President of the United States; treaty made by Panama with Colombia on same date (Malloy's treaties, I, 302, 782; 2, I349; supplement of 1913, D. I349).
} 
convention of 1863 and of which Corfu and Paxo, though now part of Greece proper, have not lost their international and neutral characteristics. ${ }^{8}$ Similar conditions attach to the narrow strip of land lying along the southerly co-terminous waters of Norway and Sweden between latitudes $59^{\circ}$ and $6 \mathrm{r}^{\circ}$ (Treaties of 1905 , and $\left.1907^{\circ}\right)$; in the Prusso-Belgian neutral ground of Moresnet a few miles southwest of Aix-la-Chapelle, laid off in I8I6 in consequence of the difficulty of precisely locating the boundaries of the territory assigned by the Congress of Vienna to Prussia on the one hand, and to the newly created kingdom of the Netherlands on the other:10 again we have the tiny neutral strip bordering the English territory of Gibraltar on its northerly edge; and the Alland Islands, some 300 in number, lying just north of the entrance to the Gulf of Bothnia, whose forts were destroyed by the French and British fleet as a part of the operations of the Crimean war in 1854 , and which at the Peace of Paris, March 30, 1856, were agreed by Russia to be kept free from fortification.11 Cape Espartel, too, is neutralized by treaty between the Powers and Morocco in $1865^{12}$ Nor should we leave this brief enumeration without a passing mention at least of the tiny governments of San Marino ${ }^{13}$ in the northern Apennines, Andorra ${ }^{14}$ in the eastern Pyrenees, Liechtenstein $^{16}$ on the Austro-Swiss border, as well as Monaco; $;^{18}$ while

'Of similar interest is the case of Cracow (Krakau) made neutral at Vienna and absorbed by Austria and Russia in 1846. For the Ionian Islands see Hertslet's Map of Europe by Treaty, nos. 355, 357, 359.

'De Martens, N. R. G. ser. 3, I, I4 seq.; N. R. G. 2me série, XXXIV, 700.

${ }^{10}$ De Martens, Recueil, 2, 32\%, 379; 3, 24.

II De Martens, N. Rec. Gén., XV, 780.

12 Treaty signed by Morocco with eleven powers at Tangier, May 3I, I865, for Io years and renewed; De Martens, XX, 350 .

${ }^{13} \mathrm{Cf}$. La République de Saint-Marin, ses institutions et ses lois, F. Daguin (1904); the electoral plan of the little state was modified in I906 by the adoption of a constitutional law:-Regolamento elettorale per l'elezione generale del consiglio principe e Sovrano.

${ }^{14}$ An excellent account is given by Leary in "Andorra, the Hidden Republic" (N. Y. I9I2); a very extensive periodical literature is to be found in French.

${ }^{18} \mathrm{Cf}$. Verfassung und Verwaltung im Fürstentum Liechtenstein, In der Maur (I907, Vienna).

${ }^{16}$ Monaco obtained in I9II the grant of a modern constitution; an account, with the constitution's text, is given in the Revue du droit Publique et de la Science Politique for I9II, pages 608-629. 
none of these latter tiny states has been subjected to any formal imposition of neutral conditions, yet by reason of their location, inherent character, and political surroundings, they are to all intents practically and permanently in the neutral class. Leaving such, however, with the foregoing mention only, we pass to a view of the neutral privileges and limitations imposed upon Switzerland, Belgium and Luxemburg by the leading powers of Europe, and with the consent of the territories themselves, the conclusive effect of which is to impart a truly international character to these governments since the end aimed at is and must be international. The conception of neutralization is essentially modern. While not unknown at earlier periods it practically takes its rise at the Congress of Vienna amid the complicated reconstructive activities made necessary by the passing of Napoleon. The documentary provisions attesting the creation of this new status are found in the first treaty of Paris May 3 oth, I8r4, and the various protocols, declarations, and formal treaties agreed upon at Vienna a few months later; in the second peace of Paris, November 20th, I8I5; and in the treaties and acts of subsequent date which were intended to round out the comprehensive scheme of the Allies. While not all that was undertaken at Vienna has survived, the modern world owes much to the neutrality features of the work of the Congress, nor is it improbable, despite discouraging apparent failure, that neutralization is destined in future days to witness an expansion rather than an annihilation of its innately beneficent purposes. The conditions and requisites of neutralization, though possessing much in common with the concept of neutrality itself, are nevertheless sharply to be distinguished by reason of the fact that while mere neutrality as a status is ordinarily an accompaniment or reflection of war, neutralization owes nothing to what is essentially fortuitous. Being intended to obviate every act or condition warlike in character within the borders of the State acknowledging it as a possession, it is in reality assimilated to the constitutional plan of the neutralized State, as it is intended to be the defence of its very existence. But in the interpretation of rights and duties of which the neutralized State must of necessity be the subject as well as the object, we turn for light to the accepted characteristics of neutrality and must find in them a guide both for the attitude of the neutralized government as well as for courses to be pur- 
sued or avoided in reference to it by all other States. In essence, neutralization is political in character; it rests its security, however, upon the sanctions of international faith and, once established, should be regarded by every civilized government as of sacred obligation; since, too, it comes into existence of necessity through international conventions, the conditions which define and limit it lie wholly without the sphere of the conjectural and exist in a form as concrete and permanent as the effects they are intended to produce. Undertaken in the interest of a widely comprehensive circle of polities, neutralization is inevitably and completely removed from the domain of the transitory or exclusive and should breathe the atmosphere of the universal only. No argument, consequently, derived from military expediency or national interest can for a moment avail to justify an infringement of neutralized borders or induce the granting of any concession whose motive springs from a warlike impulse or expedition. No demonstration is needed to support the proposition that a war-making force should never, save as refugees (and even then in disarmed internment only) cross the neutralized frontier; a refusal to permit such crossing and a resistance, if need be, to every demand of such a character is to be simply regarded as an effort to maintain conditions exacted by sacred pledge and is to be treated as such by all who would sustain well established international principles.

Neutralization as it has been interpreted with reference to Switzerland, Belgium and Luxemburg may be distinctly held then to imply a freedom, under all possible circumstances, from the presence of armed forces belonging to a foreign state provided such forces are marching with a hostile intent towards any third Power whatever, and thus, for the moment, employing the neutralized territory as a base of belligerent operations. Manifestly, such an intent would be absent in the case of an army seeking asylum or where permission might be asked for friendly transit, there being no ultimate intention of aggression in any quarter. Technically, nevertheless, even such a transit free from overt offense to the neutral Power and with no designs of conquest in view, is still a violation and to be avoided if such an avoidance may be held consonant to the principles of humanity. But beyond such exceptions, neutralization, when effected by collective international agreement, cannot be violated without a wholly indefensible breach of international faith. 


\section{SWITZERLAND}

An examination of neutralization must necessarily begin with the illustrations afforded by Switzerland's diplomatic history. The Swiss, however have not only been foremost as a nation in obtaining the benefits of war immunity in modern days, and on their own soil, but the Cantons have played no small part in the past toward promoting neutrality conditions in territory other than their own, as a glance at the neutrality agreements negotiated at the instance of the Swiss allies between France, Austria and Spain during the 16 th century for the preservation of tranquility in Burgundy, sufficiently proves. ${ }^{16 a}$ We shall begin our present examination, however, with the treaties agreed upon at the Congress of Vienna.

When the allies met at Paris in I8I4, and subsequently at Vienna, Switzerland keenly recognized its need both of territorial betterment and international protection. The position of Canton Geneva especially was one of territorial isolation, since on the west side of the lake, of which Geneva itself forms the extreme southern boundary, there stretched between the city and the confines of Canton Vaud a small portion of French territory - the county of Gex, then and now comprised in the Department of Ain and once a part of Franche-Comté. To the eastwards, across the lake, Savoy territory lay between Geneva and the borders of Valais to the north. Swiss diplomacy was therefore directed at the outset to remedy both of the foregoing conditions with the result that there were obtained certain distinct advantages of an international character which have since proved leading factors in the country's advancement and prosperity. These international features comprise, (I) enlargements of territory; (2) rights of passage and customs restrictions, in the nature of international servitudes, as against Savoy and France; and (3) a collective recognition by the Powers of the country's neutrality as a permanent condition, and the guarantee of its inviolability and independence.

The territorial enlargement consisted not only of the addition to the Swiss federal union of the cantons of Valais, Neuchâtel and Geneva, but of the expansion of certain cantons as well:the Grisons, Bern, Basel, Geneva, Neuchâtel. The first step in these various directions of advantage was taken by the Swiss

16a Léonard:-_"Recueil des Traitez de Paix," Paris, I693, vol. 2, p. 648, seq. 
Federal Assembly (Tagsatzung) which had been summoned by the President (Landammann) to meet at Zurich, the capital of the canton, which was at the moment clothed with the directorial authority, on November I5, I8I3, a month after the battle at Leipzig had announced the dawn of a new order in European affairs. On the I8th, a proclamation of neutrality was framed with the intention of preserving the country from being traversed by armies approaching on their way to France. Copies of the proclamation were promptly dispatched to Paris and to the headquarters of the allied forces.

But the Allies, despite the doubts of Russia, considering that a traversing of Swiss territory on their way to Paris could only be regarded as a step in the progress of freeing Switzerland as well as the rest of Europe, did not hesitate to advance and on December I6th reached the Swiss border. While public opinion in the Confederation was sharply divided, and a military contingent was assembled to oppose the impending violation of Swiss territory, in the end, and very shortly, friendly arguments presented by the Austrian and Russian Envoys (von Lebzeltern and Capo d' Istrias) prevailed, and on December 2Ist at two o'clock in the morning the allied troops peacefully entered. Basel, later reaching France through Belfort, Montbéliard, Pontarlier, and Geneva. Though deplored by many at the moment, it was nevertheless clearly seen then and later that the Allies instead of violating did in reality confirm Swiss neutrality by freeing and reëstablishing the land on its ancient basis of federal independence and giving to it a new quality which has not since then been impaired nor is it likely in future to be tarnished or destroyed. At the moment events moved rapidly; the Assembly, which had adjourned, was recalled to Zurich and on December 2gth, I8I3, resolved that the Napoleonic mediation constitution of 1803 must be regarded as a transition-step only toward an improved federal government. This practically conceded to the Allies a protectorate over the country, resulting later at Vienna in emancipation under a plan of alliance which, through gradual transformations, became the basis of the strong democratic federal state of to-day. At the first peace of Paris, 'May 30, I8I4, it was provided:-

"France shall acknowledge and guarantee, conjointly with the Allied Powers, and on the same footing, the political organization which Switzerland shall adopt under 
the auspices of the said Allied Powers and according to the basis already agreed upon with them."17

In pursuance of this clause it was that on March 20th, I8I5, Austria, Spain, France, Great Britain, Portugal, Prussia, Russia and Sweden united in a declaration that Switzerland as re-made by the Congress, and on the consent given by its federal Assembly (Tagsatzung), should be clothed with a perpetual neutrality guaranteed by the participating governments:-

"The Powers called upon to mediate in the arrangement of the affairs of Switzerland, in order to carry into effect Article VI of the Treaty of Paris of the 3 oth of May, I8I4, having acknowledged that the general interest demands that the Helvetic States should enjoy the benefit of a perpetual Neutrality; and wishing, by territorial restitutions and cessions, to enable it to secure its Independence and maintain its Neutrality;

After having obtained every information relative to the interests of the different Cantons, and taken into consideration the claims submitted to them by the Helvetic Legation;

- Declare: That as soon as the Helvetic Diet shall have duly and formally acceded to the stipulations contained in the present Instrument, an Act shall be prepared, containing the acknowledgment and the guarantee, on the part of all the Powers, of the perpetual Neutrality of Switzerland, in her new frontiers; which Act shall form part of that which, in the execution of Article XXXII of the Treaty of Paris of the 3oth of May, was to complete the arrangement contained in that Treaty."

Subsequent clauses provided for a union of Valais, Geneva and Neuchâtel with Switzerland, granted a right of free passage in the nature of an international servitude, with freedom from

${ }^{17}$ The treaties attesting the adjustments concluded at Paris, Vienna, and Turin in $1814-1816$, are preserved in extenso by de Martens in volumes 2, 3, 4 of his Nouvean Recueil; they are given, in the English translations made for Parliament, by Hertslet, Map of Europe by Treaty, vol. I; in Hertslet's work (4 volumes), the various documents are numbered for greater convenience of reference. The de Martens series, edited by able successors of its talented originator, still forms the standard diplomatic collection though the leading countries of the world have each their treaty series which, by reason of the many conventions of general import, each contain the more celebrated diplomatic documents. This is especially true of Russia and Austria: a notable collection was made by F. Martens for Russia, and Neumann de la Woestyne for Austria. 
customs duty over the highway known as the Route de Versoix, connecting Geneva with Vaud, in fulfilment of a stipulation in the first peace of Paris, and agreed to obtain for Geneva additional territory on the Savoy side of the Lake (Hertslet No. 9). Two weeks later by a protocol of March 2gth, it was agreed that Geneva should be given several adjoining Savoyard communes and that it should acquire a right of passage similar to that of Versoix over the great Simplon highway leading north from the city along the Lake's easterly front to the Alpine pass commencing at Brieg in Valais; a concluding clause provided as above stated for the future creation of certain free tariff areas in Savoy similar to one already agreed upon with France on the Lake's westerly side:

PROTOCOL OF MIARCH 29, I8I5

"Art. I. His Majesty the King of Sardinia places at the disposal of the High Allied Powers that part of Savoy which is situated between the river Arve, the Rhone, the limits of that part of Savoy occupied by France, and Mount Salève, as far as Veiry inclusive, together with that part which lies between the high road called the Simplon, the Lake of Geneva, and the present territory of the Canton of Geneva, from Venézas to the point where the River Hermance crosses the said road, and from thence, following the course of that river to where it enters the Lake of Geneva, to the east of the village of Hermance (the whole of the road of the Simplon continuing to be possessed by His Majesty the King of Sardinia) in order that these countries may be united to the Canton of Geneva; with the reservation; however, of determining more precisely, by Commissioners respectively appointed, their limits, particularly of that part which relates to the demarcation above Veiry and on Mount Salève. His Majesty renounces for himself and his successors in perpetuity all rights of Sovereignty, and other rights which may have belonged to him over all the places and territories comprised in this line, without exception or reservation.

COMMUNICATION BETWEEN GENEVA AND THE VALAIS, SIMPLION AND VERSOY ROADS

Art. II. His Majesty agrees, that the communication between the Canton of Geneva and the Valais by the road of the Simplon, shall be established; in the same manner as it has been agreed to by France, between Geneva and the Canton of Vaud, by the route of Versoy. 


\section{PASSAGE OF TROOPS}

A free communication shall be at all times granted for the Genevese troops, between the territory of Geneva and the jurisdiction of Jussy, and such facilities shall be allowed as may be necessary for proceeding by the lake to the road of the Simplon.

Art. VI. His Majesty consents, from the same motives, to make arrangements with the Canton of Geneva, for facilitating the conveyance from his states of articles intended for the consumption of the Town and Canton."

It is on this latter paragraph, as we shall presently notice, that the peculiar system of free tariff-zones was afterwards constructed as an element in the ends sought to be attained in the establishment of Swiss independence and neutrality.

At Zurich, May 27th, I8I5, the Swiss Assembly gave in its formal adhesion to the plan of the Allies in the following resolutions:

"The Diet accedes, in the name of the Swiss Confederation to the Declaration of the Powers assembled at the Congress of Vienna under date of the 20th March I8I5, and promises that the stipulations contained in the 'Transaction' inserted in this Act shall be faithfully and religiously observed.

No. 2. The Diet expresses the eternal gratitude of the Swiss nation towards the high Powers who by the above declaration assigned to them with a boundary far more advantageous its ancient important frontiers; unite three new Cantons to the Confederation; and promise solemnly to acknowledge and guarantee the perpetual neutrality of the Helvetic Body as being necessary to the general interest of Europe. The Diet feels the same sentiments of gratitude for the uniform kindness with which the august Sovereigns have exerted themselves in bringing about a reconciliation of the differences which have arisen between the Cantons."

Accordingly the Vienna Congress Act of June 9th, I8I5 (the Vienna Final Act) contained the following stipulation in Article 84:-

"The declaration of the 2oth March addressed by the Allied Powers who signed the Treaty of Paris to the Diet of the Swiss Confederation, and accepted by the Diet through the Act of Adhesion of the 27th May, is confirmed in the whole of its tenor; and the principles 
established as also the arrangements agreed upon in the said declaration shall be invariably maintained."

Thus the principle of a Swiss permanent neutrality received the approval and guarantee of the Powers.

Through the cession to Geneva of these several communal districts by Sardinia and France their territories fell of course within the neutralization plan. And inasmuch as Upper Savoy was practically detached by great mountain ranges from the remainder of the Sardinian territories, it had not been deemed inappropriate, and in the interest of both Savoy and Geneva, to assimilate it to the new international design. Consequently Article XCII of the Vienna Congress Treaty, June 9th, 18I5, declared:-

"The provinces of Chablais and Faucigny, and the whole of the territory of Savoy to the north of Ugine, belonging to his Majesty the King of Sardinia, shall form a part of the neutrality of Switzerland as it is recognized and guaranteed by the Powers.

PASSAGE OF TROOPS

Whenever therefore the neighboring Powers to Switzerland are in a state of open or impending hostility the troops of his Majesty the King of Sardinia which may be in those provinces shall retire and may for that purpose pass through the Valais, if necessary. No other armed troops of any other power shall have the privilege of passing through or remaining in the said territories and provinces excepting those which the Swiss Confederation shall think proper to place there; it being well understood that this state of things shall not in any manner interrupt the administration of these countries in which the civil agents of his Majesty the King of Sardinia may likewise employ the municipal guard for the preservation of good order."

We have here, manifestly, a valuable definition of the true practical ends sought by international neutralization. The troops of neutral Switzerland and none other may, if need arise, occupy neutralized Savoy. It was not, however, until the second peace of Paris concluded towards the end of the same year (November 20, I8I5-Hertslet No. 40) that Swiss neutrality received its final charter from the Powers who at the same time widened the neutral limits to comprise the southerly portions of Upper Savoy:- 
"The neutrality of Switzerland shall be extended to the territory situated to the north of a line to be drawn from Ugine, that town being included, to the south of the Lake of Annécy, by Faverge, as far as Lecheraine, and from thence by the Lake of Bourget, as far as the Rhone, in like manner as it was extended to the Provinces of Chablais and Faucigny, by Article XCII of the Final Act of the Congress of Vienna." ${ }^{\prime 18}$

As a parallel step to this additional neutralization, Switzerland acquired through the same instrument a stipulation that the fortifications of Huninguen just northwest of Basel should be demolished, the French government engaging not to reëstablish them and not to replace them by other fortifications at a distance of less than three leagues from the town of Basel.

In a companion document executed the same day by Austria, France, Great Britain and Russia and termed Act of Recognition and Guarantee of Swiss Permanent Neutrality (Hertslet No. 43) the Powers "formally recognize Switzerland's perpetual

${ }^{18}$ A well known instance of early effort to create permanent neutrality for the Savoy districts to the south and east of Lake Geneva is part of the history of the War of the Spanish Succession. At the instance of the then reigning Duke of Savoy, the Swiss cantons Bern and Friburg sent envoys to the French Marshal in command at Chambéry. But while Louis XIV was willing to concede the Savoyard demand, the Swiss Assembly failed to agree upon any definite plan of mutual regulation, and in 1706 the French forces evacuated the region and thus the question fell into abeyance. But the reason inducing such a step as had been aimed at lay inherent in the geographical location of these provinces situated in fact upon the high road leading from Franche-Comte to Italy, and they were, therefore, ever exposed to danger in case of war between Austria and France and exceedingly difficult of defence by the Prince of Piedmont. When, consequently, Saint-Marsan, Sardinian envoy at Vienna in 1815 , brought the project before the Congress it was but the revival of an ancient conception and was now intended to avert the possible risk of Upper Savoy being annexed to Switzerland. In the event, the problem was solved as narrated in the text. Another occasion of interest in this connection was furnished in I7r5 when the Marquis de Chateauneuf presented on the part of France a Memoir to the StatesGeneral proposing to create, on the Austrian Netherlands frontier, in concert with the emperor, a status of lasting neutrality "au bien général et au repos de l'Europe" (Dollot, les origines de la neutralité de la Belgique, page 556 seq.). This was à propos of the celebrated Barrier treaties with the Empire by which Holland was allowed to maintain an extreme Southerly line of forts at some distance from its own geographical frontiers. The French suggestion would have resulted in a neutralized zone "toujours exempt des Malheurs de la guerre." 
neutrality and guarantee its territorial integrity and inviolability within the (geographical) limits settled by the Congress of Vienna and by this treaty and the protocol of the 3 rd of November hereto annexed" (Hertslet No. 40). The treaty comprises a similar recognition and guarantee of nestrality for the Savoy districts :-

"The same being entitled to participate in the neutrality of Switzerland equally as if they belonged to that country. The Powers who signed the declaration of the 2oth March acknowledge in the most formal manner by the present act that the neutrality and inviolability of Switzerland and her independence of all foreign influence enter into the true interests of the policy of the whole of Europe. They declare that no consequence unfavorable to the rights of Switzerland with respect to its neutrality and the inviolability of its territory can or ought to be drawn from the events which led to the passage of the Allied Troops across a part of the Helvetic State. That passage, freely agreed to by the Cantons, was the necessary result of the frank adhesion of Switzerland to the principles avowed by the Powers which signed the treaty of alliance of March 25th. The Powers acknowledge with satisfaction that the conduct of Switzerland under these trying circumstances has shown that she knew how to make great sacrifices for the general good and for the support of the cause which all the Powers of Europe defended, and that, in fine, Switzerland has deserved the advantages which have been secured to her, whether by the arrangements of the Congress of Vienna, by the treaty of Paris of this day, or by the present Act to which all the Powers in Europe are invited to accede." (Hertslet No. 43.)

These provisions, as settled in June, I8I5, were accepted by the Swiss Assembly August Ist at Zurich, and in the year following the Assembly ratified the confirmatory clauses of the second peace of Paris, all of which now became an integral part of the constitutional and international framework of the confederation as constructed under the new federal constitution (Bundesakt) given by the Vienna Congress. As thus carefully outlined, Swiss neutrality is a recognized element of the European international system. When, however, in the spring of I859 a serious conflict between Austria and Sardinia appeared unavoidable, Switzerland hastened to define its position in an executive proclamation:-

"The Federal Council, therefore, declares in the most formal manner, that, if the Peace of Europe should be 
disturbed, the Swiss Confederation will defend and maintain, by all means at her disposal, the Integrity and Neutrality of its Territory, to which she has a right in her character as an Independent State, and which has been solemnly recognised and guaranteed to her by the European Treaties of I8I5. She will loyally accomplish this mission equally towards all.

The Treaties of I8I5 declare, besides, that certain portions of the Territory of Savoy, which form an integral part of the States of His Majesty the King of Sardinia, are comprised in the Swiss Neutrality."

After calling attention to the various treaties and protocols which we have reviewed touching the neutralization of Switzerland and the bordering Sardinian districts, and maintaining that such portions of Savoy as had been brought by these Acts within the neutralization shield should enjoy the same international guarantee as Switzerland itself, the Council concluded:-

"Finally, the Federal Council entertains the hope that these Declarations, which are as frank as they are loyal, will be favourably received, and that the High Powers will know fully how to appreciate the position in which it has thought it to be its duty to place itself in the actual political situation and in anticipation of eventualities which may arise."

To this the French government replied:-

"In acknowledging the receipt of the communications which has been made to him, the Minister declares that he renders entire justice to the sentiments which have inspired this measure, and he cherishes the hope that the dispositions of the other Powers not being less favourable than those of the Government of his Majesty the Emperor, in regard to, respect for, and the maintenance of, Swiss Neutrality, the Public Law which consecrates it cannot in any case, run any danger." (Hertslet No. 290, vol. 2, p. 1356.)

Immediately upon the promulgation of the Austrian ultimatum to Sardinia, April 19, I859, French troops began to move from Culoz below Geneva towards Piedmont through the southern borders of Upper Savoy and along the Mont-Cenis road. Switzerland promptly pointed out to the British Foreign Office that this movement might involve the violation of Savoy neutrality, and, on these views being laid before the French Foreign Office, Count Walewski, though assenting to the force of the suggestion by stopping the transit of the French forces through Upper 
Savoy, nevertheless disclaimed any actual violation of the neutralized districts since the route taken by the army had probably lain south of the neutrality line agreed upon in $18 \mathrm{r} 5$, and since too, the actual line having never been surveyed, its precise course remained in doubt. Subsequent to the treaty of peace signed at Zurich, November 10, 1859, it became evident that France intended to annex the districts of Upper Savoy as well as Nice by way of compensation for assistance given in the war, and Swiss apprehension was again aroused less the much-prized Savoy neutralization should now disappear through French control of the territory. Napoleon promptly met the Swiss protest by incorporating in the treaty of annexation signed at Turin, March 24, I860, a stipulation fully recognizing the validity of Savoy's neutrality features as long established by international agreement: "It is equally understood," runs the convention of I860, March 24:

"that his Majesty the King of Sardinia cannot transfer the neutralized parts of Savoy except on the conditions upon which he himself possesses them, and that it will appertain to his Majesty the Emperor of the French to come to an understanding on this subject both with the Powers represented at the Congress of Vienna and with the Swiss Confederation, and to give them the guarantees required by the stipulations referred to in this article." (Hertslet Nos. 307-315.)

There remain to be briefly considered in this connection the well-nigh unique provisions, complementary to neutrality, and, regard being had to local needs, as beneficial as neutrality itself, pursuant to which the districts lying on the northwest, southeast and east of Canton Geneva have been endowed with an immunity from customs duties. Regarded in the light of their peculiar exemptions, these portions of France and Savoy are known as the free zones (zones franches du pays de Gex at de la Haute- Savoie). ${ }^{19}$ Of these districts the county of Gex, when the Congress of Vienna met, lay, as already stated, between

${ }^{19} \mathrm{Cf}$. the account of the zones in the message addressed to the Swiss Federal Assembly by the federal executive council (Bundesrat), April I4, I908, preliminary to the conclusion of a new treaty with France. The entire subject is considered in great detail by Hilty (long the Professor of Constitutional and International Law at Bern) in his article "die Genfer Zonen" in the Politisches Jahrbuch der Schweizerischen Eidgenossenschaft for 1894-5 at pp. 202-315. 
the Swiss cantons of Geneva and Vaud, a portion of it being later assigned to Geneva in order to provide a territory along the west side of the lake connecting directly with northwest Switzerland. The Savoy districts where such zones lie were formerly part of Sardinia, but, since I860, have belonged to France. It is to be carefully noted that these duty-free zones are not precisely identical in area with the neutralized districts adjoining Swiss territory of which we have spoken, but they are, so to speak, superimposed upon the greater part of them. On the French side is a zone of this nature which comprises all that part of the county of Gex extending from Ferney and the river Valserine to the Jura summits and not ceded to Geneva; on the Italian side the zones comprise all but the extreme southern portion of Upper Savoy. In Gex the conception of freedom from customs exactions is by no means new but was familiar to the days of the old French monarchy. As the zones, however, stand at the present time, the county of Gex and the zone-portions of Savoy immediately surrounding Canton Geneva on the south and east date from the Congress of Vienna (Protocol of March 29, I8I5, Hertslet No. IO), the treaty between France, Sardinia and Geneva signed at Turin March 16, 1816 (Hertslet, 52) the protocol to the second peace of Paris, November 3, I8I5, article 5 (Hertslet No. $3^{8}$ and 40) and the imperial decree of Napoleon III, March 24, I860, promulgating the above mentioned treaty of annexation to France of Nice and Savoy (Hertslet No. $3^{\mathrm{I}} 3$ ). The ends to be attained by these zones were reached by effecting a retirement of customs lines for a few miles along the French and Sardinian borders (now wholly French) as stated clearly in a protocol to the second peace of Paris, Article V:-

"The French Government having consented to withdraw its lines of customs and excise from the frontiers of Switzerland, on the side of the Jura, the Cabinets of the Allied Powers will employ their good offices for inducing His Sardinian Majesty to withdraw in like manner, his lines of custom and excise, on the side of Savoy, at least upwards of a league from the Swiss frontiers, and on the outside of the great road of Salève and of the mountains of Sion and Waache."

After France had obtained possession of the country, Napoleon III issued a proclamation carefully delimiting the custom-free area and confirming the Savoy zone-régime, and greatly enlarg- 
ing its boundaries, the regulations there to be enforced to be assimilated to those heretofore current in the county of Gex. In later days the Third Republic has perpetuated these zone features through successive systems of regulation, the latest being the treaty between France and Switzerland in I908. Customs administration is carried on in these special districts through a system admitting certain classes of food products and raw material to be used in manufacture either, (I) quite free of duty; or (2) with a moderate duty levied after the introduction of a fixed maximum amount; or (3) subject to the levy of a fixed though greatly reduced excise. The system is equally prized by the French and Swiss; taken together with the neutrality features of Savoy (Gex is not neutralized), it forms no inconsiderable element in Switzerland's endowment of free institutions.

\section{BELGIUM}

We have seen that in Switzerland the neutralization of the country was at the Congress of Vienna expressly recognized by the great powers of Europe while its territorial integrity and inviolability were guaranteed; in the case of Belgium we shall find, however, that it is the neutrality and independence of the country that fall within the international guarantee; for Luxemburg we shall note in conclusion there is an international guarantee of neutrality alone. There can, nevertheless, exist no doubt concerning the true significance and force of these varied international declarations if we regard the history and territorial aspects of the three several countries. In each case they are alike intended to be wholly preserved from even a demand of armed intrusion or from becoming to the slightest extent either a theatre of war or an accessory to hostile procedure toward other states or the host of an armed force or, in any degree, the scene of military conflict save in vindication of neutral status or in the suppression of disorder within their own borders. A glance at the historical development of political unity in the regions lying between France, Germany, and the North Sea is essential to an understanding of the diplomatic and international aspects of a country which more than any other has lent itself to projects aimed at the development of the best impulses in government and a maintenance of peace in international life.

The present kingdom of the Netherlands occupies a part of the Low Countries which in the later Middle Age were com- 
prised in the possessions of the House of Burgundy; within the Burgundian Circle, ${ }^{20}$ too, were the various districts now forming Belgium. The conclusion of the Peace of Utrecht, in I7I3, assigned the larger portion of what we now know as Belgium to the House of Austria under the designation of the Austrian Netherlands; forming an important geographical element of the region though not under Austrian domination was the great Bishopric of Liège together with the Abbey Lordship of Stablô and Malmédy on the north, and the tiny duchy of Bouillon on the south; the mediæval duchy of Luxemburg lay wholly within the Spanish jurisdiction assigned to the Hapsburgs, the archduke, who was also Emperor, casting the vote of Burgundy in the Imperial Reichstag at Regensburg. In I795, as a sequel to the victories of Jemmapes and Fleurus by the French revolutionary forces, these various territories came within the power of France, and after Napoleon's conquests of the country to the north, they became merged in the French Empire and the Kingdom of Holland. At the first Peace of Paris, May 30, I8I4, and in the treaty made at The Hague July 21 following, Nesselrode, Hardenberg, Metternich and Castlereagh decreed a new state to be formed by the territories of the late United Provinces of the Netherlands, the Austrian Netherlands, Liège (Lüttich) and the small secularized adjacent districts not absorbed by Prussia. The political object of the plan was announced to be "the establishment of a state of equilibrium in Europe," the creation, that is, of an intermediate government designed to illustrate a phase of what we to-day term the balance of power, -an expression which occurs in the treaties signed at Utrecht at the conclusion of the war of the Spanish succession in $1713 .{ }^{21}$ This new kingdom of the Netherlands was formally

${ }^{20}$ The Circle (der burgundische Kreis) contained in the eighteenth century, a part of the duchy of Brabant, the Lordship of Mechlin, parts of the duchies of Limburg, Luxemburg and Geldern, a part of the county of Flanders, with portions of the counties of Hennegau and Namur; Liège (Lüttich), Bouillon, and Stablô (or Stavelot) lay outside these boundaries. The archduke of Austria was director and executive Prince (Kreisauschreibender Fürst) of the Circle. An accurate description is that of Wolff in his "die unnittelbaren Theile des ehemaligen römisch-deutschen Kaiserreiches" (I873).

${ }^{21}$ The treaties of Utrecht are in Dumont's great collection; the Convention of August I3, I7I3, is in volume VIII of the series at page 40I, etc: "par les mesmes raisons et Motifs du Bien public, du Repos, et de 1'Équilibre de l'Europe." 
handed over by the Congress of Vienna to the Prince of OrangeNassau who thus regained his own Holland country with much to the south, the Luxemburg district being now erected into its former political status of a grand duchy and given to the Prince to hold as Grand Duke of Luxemburg in personal union with the kingdom of the Netherlands and as compensation for his hereditary Nassau territories which had been given to Prussia; the grand duchy of Luxemburg, too, was made a member of the new German confederation with three votes in the Plemum and one vote in the Inner Council of the Bund. The city of Luxemburg, furthermore, was agreed upon as a federal German fortress (Hertslet No. 27), being by reason of its remarkable natural position easily capable of becoming what it was afterwards made by Prussian engineers-the strongest fortress in Europe. A treaty between Prussia and the Netherlands signed November 8, I8I6, provided that the two sovereigns should jointly garrison the fortress, the King of Prussia to appoint the Governor. This plan was confirmed by conventions between Great Britain and the Netherlands November I6, I8I6, Austria and the Netherlands March I2, 1817, and Russia and the Netherlands April I7, I8I7, the whole being ratified in the General Convention (Récès) of Frankfort July 20, I8Ig (De Martens, N. R. Gén. IV, 604-6IO). These various arrangements, however, received a shock when the Revolution at Paris in July, I83o, spread to Brussels and resulted in a revolutionary movement sufficiently determined in character to compel a conference at London of the ambassadors representing the five great Powers; here it was determined in the following year to recognize the separation of the Belgic country from the Crown of the Netherlands, and a new territorial alignment was resolved upon by virtue of which a part of Luxemburg, Bouillon and Stavelot, and the Belgic provinces were to form a new kingdom bordering Holland on the south and under the rule of Leopold of Saxe-Coburg, leaving the Luxemburg fortress, nevertheless, with the district necessarily appertaining to it still a grand duchy of Luxemburg and subject to the Crown of the Netherlands, in personal union. The treaty providing for this new status was signed November I5, I83I, and contained the following important clauses:-

Article VII. Belgium, within the limits specified in Articles I, II, and IV, shall form an independent and 
perpetually neutral state. It shall be bound to observe such neutrality towards all other states.

Article XXV. The Courts of Great Britain, Austria, France, Prussia, and Russia guarantee to his Majesty the King of the Belgians the execution of all the preceding articles."

The convention, executed by Esterhazy and Wessenberg for Austria, by Talleyrand for France, Palmerston for Great Britain, Bülow for Prussia, Prince Lieven and Count Matuszewic for Russia and Van de Weyer on the part of Belgium, was formally ratified and ratifications exchanged at London at varying dates between November 22, I83I, and May 4, I832.

It being found necessary to put pressure on the Netherlands, Leopold called on Great Britain and France to support the convention's guarantee, and treaties were concluded between Belgium and France (November ro, 1832) and Belgium and Great Britain October 22 of the same year, providing for seizure of Dutch vessels found in British or French ports, for a blockade of the Dutch coast, and for the entry of French troops, if found requisite, to expel the Dutch forces from Antwerp. In the end, Holland yielded, and, finally, on March I4, I838, it notified the guaranteeing powers of its willingness to adhere to the treaty of London of November 15, 1831. New treaties were now concluded between the five powers, Belgium, and Holland, on April I9, I839, delimiting frontiers, equitably apportioning the public debt of the Netherlands between itself and Belgium, and establishing liberal terms for navigation of the Scheldt (Escaut), the Meuse, etc., and affirming, on the part of the Powers, the first 24 articles of the treaty of November I5, I83I, which had contained 27 articles, the twenty-fifth having assured, as above stated, a general guarantee of those preceding it. In the new conventions of 1839, the 24 articles appear as annexes, and Article $I$ of the treaty between the Powers and Belgium declares "that the Articles hereunto annexed and forming the tenor of the treaty concluded this day between His Majesty the King of the Belgians and His Majesty the King of the Netherlands, Grand Duke of Luxemburg, are considered as having the same force and validity as if they were textually inserted in the present Act, and that they are thus placed under the Guarantee of their said Majesties." 
Thus the original Article VII of the treaty of 183 I announcing Belgium as a neutral state came within a collective international agreement creating, as completely as the most serious pledge of the governments concerned could effect it, a permanent neutralization of Belgium territory and protection from violation or intrusion by any belligerent force whatsoever, and under any pretext. The execution of these treaties, in so far as they could concern the Germanic Confederation, was ordered ratified by the Frankfort Assembly (Bundestag) through the Austrian and Prussian Ambassadors at London as plenipotentiaries in its behalf and ratifications were exchanged at London, June 8 , I839, with the signatory Powers, Prussia and Austria thus taking a leading part in the result.

The effect of these various diplomatic arrangements was of course acknowledged to impose obligations on Belgium touching its international attitude as well as upon the great Powers with respect to Belgium itself. These obligations were questioned by none although they were construed, and properly, to refer to possible operations of an essentially belligerent character only, and on the European continent. ${ }^{22}$ It was therefore not thought to infringe the treaties should Belgium fit out an armed contingent for the succor of Donna Maria in Portugal when that Princess was threatened in 1832 by a domestic insurrection on the part of her uncle Don Miguel; nor again when the unfortunate Maximilian of Austria attempted thirty-two years later to found an empire in Mexico; nor, once more, on the occasion of the Boxer disturbance in China, in I900, was it considered a breach of Belgium's permanent neutrality to assist in the rescue of Europeans at Peking, although the rapidity of movement of events in China rendered the actual dispatch of Belgian troops unnecessary. ${ }^{23}$

\section{LUXEMBURG}

Lastly, we come to the treaties providing for the permanent neutrality of the grand duchy of Luxemburg. Here it may be

\footnotetext{
$=2$ The conventions and other documents are given in full by $\mathrm{De} \mathrm{La}$ Véga, in his Traités de la Belgique, vol. I. The best general account is that of Descamps, "La Neutralité de la Belgique." The principal treaties are, of course, to be found in De Martens and Hertslet.

${ }^{23}$ Descamps, p. 480 et seq. The Act of Accession on the part of the Germanic Confederation, is given in De la Véga, Traités de la Belgique, p. 220. 
said, in passing, that the death of the King of the Netherlands in 1890 , without male heirs, transferred the succession in the grand duchy to the late King's agnates of Orange-Nassau, the crown thus being given to his cousin Adolphus whose granddaughter Marie Adelaide is sovereign of the little country to-day by reason of the somewhat peculiar provision in the Nassau family compact (Erbvëreinigung) which permits, in case of a failure of all heirs male, the crown to be taken by the nearest female heir. ${ }^{24}$

Between the settlement of $I 839$ above recounted and the conclusion of the war in 1866 between Prussia and Austria, Luxemburg, diminished in size, as we have seen, continued to be ruled in personal union by the holder of the Netherlands crown. But on the dissolution of the German confederation, of which Luxemburg was a member, a question arose as to the future political association of the little country which lay geographically isolated from its titular sovereign and yet possessed an impregnable fortress garrisoned by Prussian troops under the former arrangement of the confederation. Napoleon III proposed to the King of Holland that Luxemburg be transferred to France, and while neither Holland nor Luxemburg seemed to object, Prussia was firm in remonstrance, with the result that a conference of the Powers was called to meet at London in May, 1867, and determine Luxemburg's political fate. As the only solution of what threatened to be a dangerous European situation, it was there agreed that Luxemburg's fortress be demolished and the Prussian garrison be dismissed, while the little country itself was to be recognized as neutral in permanence. Such a mere recognition, however, was not thought sufficient by Prussia, and in the carefully preserved protocol of the conference, we are told that the Prussian ambassador moved to change the clause of neutrality as presented by Lord Stanley to the conference, in order to give it the character of an absolute and collective international neutrality guarantee; it was therefore agreed that it be worded as follows: ${ }^{25}$

\footnotetext{
${ }^{2}$ Duke Adolphus had lost his ducal crown of Nassau when that country was absorbed by Prussia in 1866; the Nassau succession-compact was amended and interpreted by a supplemental statute ratified April 16, 1907, by the Luxemburg Assembly.

${ }_{25}$ The facts and documents touching the international status of Luxemburg are to be found in the valuable collection made by Ruppert, Secretary-General to the Government, and published at Luxemburg in I892:
} 
"Art. II. The Grand Duchy of Luxemburg within the limits of the Treaty of April I9, I839, and under the guarantee of the five powers, shall henceforth form a perpetually neutral state. It shall be bound to observe the same neutrality towards all other states. The high contracting parties engaged to respect the principle of neutrality stipulated in the present article. That principle is and remains placed under the sanction of the collective guarantee of the powers signing the present treaty, with the exception of Belgium, which of itself is a neutral state."

In this way a most serious international obligation was entered upon and at the instance of Prussia. That it is permanently conclusive upon that power and upon the German Imperial Government also would appear to be beyond dispute.

"Le Grand-Duchẻ de Luxembourg dans ses Relations Internationales. Recueil des traités, conventions et arrangements internationaux et dispositions législatives diverses concernant les étrangers." At pages 149-307, and 587-605, the protocols and conventions touching Luxemburg's international status are given in most precise detail. An accurate summary of the protocol with the text of the treaty of May, I867, are in De Martens, XVIII, 432. The treaty-text is in Hertslet also. It was on May 7, I867, that, in the London Conference at the British Foreign Office, Prussia moved as an amendment to the British draft of article z:-“ce principe" (Luxemburg's neutrality) "est et demeure placé sous la sanction de la garantie collective (ou commune) des Puissances signataires du présent traité, à l'exception de la Belgique qui est elle-même un État neutre." The clause, as proposed by Prussia, was debated, and, on the following day, the Prince de la Tour d'Auverge, on the part of France, assenting, it was adopted by all the Powers and became a pledge of unassailable strength. It was pointed out by Van de Weyer (Belgium) that in the conventions of 1839 Belgian neutrality and independence were expressly guaranteed by each of the Great Powers in an individual treaty. (Ruppert, loc. cit., p. 594.) In order, at the same time, to authoritatively cover the question of Belgium's right to strengthen its frontier against violation, the following declaration was annexed, on motion of Belgium, to the treaty of May II, I867, signed by the five Powers together with Italy, the Netherlands and Belgium;- "it is understood, that Article III in no way affects the right of the other neutral Powers to maintain, and if necessary to improve, their Fortresses and other means of defence." ("Adopté à l'unanimité," May II, I867.) (Hertslet, no. 406; Ruppert, loc. cit., page 597.)

In the carefully considered case of Terlinden $v$. Ames, decided by the U. S. Supreme Court, February 24, I902 (I84 U. S. 270), it was held that the adoption by Germany of an imperial constitution in $187 \mathrm{I}$ does not necessarily invalidate extradition process between the Empire and the United States under a treaty made by the latter with Prussia in I852; the treaty obligation of Prussia is not weakened by the imperial union. 
On the occasion of the Franco-Prussian war, both belligerents agreed by separate treaties with Great Britain to respect Belgium's neutrality so long as each of the Powers concerned would observe the treaty conditions. ${ }^{26}$ While after the battle at Sedan, as well as after the surrender at Metz, French refugee soldiers in great numbers crossed the Luxemburg and Belgian frontiers to escape the Prussians, this was not considered a sufficiently serious transgression of neutrality principles to warrant definite action beyond an informal remonstrance on Prussia's part; nor was Bismarck lacking in candor as to the neutrality of Switzerland at the same period, as a letter of his preserved in the Swiss Archives clearly shows. He there agrees to respect the little country's neutrality as outlined at Vienna years before, and pronounces the German Government determined to uphold the agreements contained in those proceed-

${ }^{3}$ When, on the I7th of July, 1870 , war was on the eve of being declared against Prussia by France, Lord Loftus, in a despatch to Earl Granville from Berlin, advised the British Foreign Office that both France and Prussia (Bismarck) had officially notified Luxemburg of their intention to severally respect the Grand Duchy's neutrality. This attitude was, later, extended to Belgium by treaties between Great Britain, France and Prussia. On the following day the Swiss Federal Council (Bundesrat), in an identical note to the various Powers signed by the President and Chancellor of the Confederation, declared, appealing to the treaties of Vienna and Turin, that it would maintain its neutrality and the integrity of its territory, and would "energetically repulse every aggression"; the Council recalled Switzerland's right to occupy neutralized Savoy by military force, and, should such a step become necessary, it would exercise the right through "an arrangement to that effect with the French Imperial Government." France, through the duc de Grammont, on receiving the note, offered no objections to the position taken, but announced its willingness, should the event require such a step, to conclude an adequate adjustment. These documents are witnesses to the meaning attached by the Powers to Switzerland's neutral immunity. They precisely voice the clear exposition given later by Professor Arendt of Louvain University touching neutral immunity in his well-known "Essai sur la Neutralité de la Belgique" published in 1845; and who says (p. I22) of belligerent passage over neutral territory:- "la guerre une fois déclarée, il n'y a plus de passage innocent, tout mouvement de troupes d'un belligérant peut et doit être considéré par son adversaire comme se reliant d'une façon quelconque aux opérations militaires de l'ennemi, et s'il a lieu sur on par le territoire du neutre, comme incompatible avec la neutralité de ce dernier." Should a privilege of passage, nevertheless, be requested, the neutral "peut l'accorder on la refuser" though wholly impartially; nor may a belligerent in any wise regard the neutral's decision so made as a "casus belli." The French and 
ings. ${ }^{27}$ They were recognized by the great Chancellor as possessing a binding force superior to all passing pressure of necessity or opportunity, being founded in fact upon principles whose preservation inviolate must be considered indispensable to the existence and progress of modern civilization.

YALE UNIVERSITY, December, I9I4.

\section{Gordon E. Sherman.}

Prussian treaties were signed at London by Granville with the representatives of Prussia and France August II, I870; they bound Great Britain to maintain by force, in coöperation with either belligerent, the independence and neutrality of Belgium if violated by the other belligerent. The treaties were concluded for the period of the war and twelve months thereafter when "à l'expiration de ce temps, l'indépendance et la neutralité de la Belgique continueront, en ce qui regarde les Hautes Parties Contractantes, a reposer, comme jusqu'ici, sur l'article $\mathrm{I}^{\mathrm{er}} \mathrm{du}$ Quintuple Traité du 19 Avril, 1839"; (de Martens, loc. cit., XIX, 59r-595). Although during the war Luxemburg sympathy had been overtly on the side of France, Bismarck declared that Prussia had no intention of denouncing the treaty of 1867 by which the position of Luxemburg was defined and secured. (Hertslet, vol. 3, p. Igo3.) On the other hand, after Prussia had occupied Metz and the French forces had failed to pierce the German lines at Belfort, Bourbaki's veteran army, now commanded by General Clinchant, surrendered to Herzog, who had marshalled forces on the Swiss frontier for defence of its neutrality. The surrender treaty was made near Pontarlier (Verrières) February I, I87I (de Martens, loc. cit., XIX, 639). The troops were interned by the Swiss until the conclusion of the war, all but the officers giving up their arms which were returned to them when peace was made.

${ }^{27}$ Berlin, le 24 Juillet, I870, "Le soussigné chancelier de la Confédération d'Allemagne du Nord ... a accuelli avec une vive satisfaction la déclaration du conseil fédéral que la Suisse maintiendra et défendra . . . sa neutralité et l'integrité de son territoire; et il n'hésite pas à déclarer que l'Allemagne respectera scrupuleusement la neutralité de la Suisse garantie par les traités, et qu'elle compte avec une entière confidance sur son maintien par les forces militaires de la Confédération Helvetique. La fidélité aux traitès dont l'Allemagne a constamment fait preuve et les relations de bon voisinage qui existent si heureusement entre les deux pays, offrent à la Suisse un gage de plus que sa neutralité sera consciensement respectée par 1'Allemagne." (Hilty, "Die Neutralität der Schweiz in ihrer heutigen Auffassung," Bern, I889, page 52, note.) 